\title{
Effect of Marketing Strategy and Service Quality Against the Decisions of Parents
}

\author{
Safitri Amelia ${ }^{1}$, Hartini Salamah ${ }^{2}$, Mohammad Sofyan ${ }^{3}$ \\ ${ }^{1}$ Marketing Management at Ibn Chaldun University, Jakarta \\ ${ }^{2}$ Faculty of Economics, Ibn Chaldun University, Jakarta \\ ${ }^{3}$ Institute of Social Sciences and Management STIAMI, Jakarta \\ Correspondent: safitriamelia53@gmail.com
}

Submitted: 5 August 2019. Revised: 25 August, 13 Sept 2019. Published: 30 October 2019.

\begin{abstract}
This study aims to analyze and determine the effect of marketing strategy variables and service quality on parents' decisions. In this study, the dimensions of marketing strategies include products, prices, promotions, places, people, processes and physical evidence. Service quality dimensions include reliability, responsiveness, confidence, empathy and tangibility. Quantitative methods with multiple linear regression analysis were processed using SPSS for windows version 22. The results showed that there were simultaneously the effects of marketing strategy and service quality variables on parents' decisions. Partially, the marketing strategy variable did not significantly influence the parents' decisions at PAUD Al Hidayah Pertiwi. While service quality variables significantly influence the decisions of parents of students in PAUD Al Hidayah Pertiwi.

Keywords: Marketing Strategy, Service Quality, Parents' Decisions.
\end{abstract}

\section{INTRODUCTION}

Education is a basic need for human beings that is very important, without education the wheel of life will not develop, because education is one of the foundations in the progress of a nation, the better the quality of education held by a nation, the better the quality of the nation. In order to make efforts to build a good nation, Early Childhood Education (PAUD) as a proper and good initial education that can shape intelligence (mental abilities that involve rational thought processes) which is to shape character is certainly very appropriate for growth and development.

School is an institution established to achieve education. To achieve this goal, each school has its own vision and mission. One thing that can be done to achieve the vision and mission certainly involves various related parties in managing and developing the right strategy.

Early Childhood Education (PAUD) is a process of guidance in the growth and development of children ranging from the age of two to six years that includes physical and nonphysical by providing stimulation for physical, spiritual (moral and spiritual), motor, mind, emotional and social development right so that children grow and develop optimally. The importance of education at this time is often referred to as the golden age. Awareness of the importance of early childhood education aims to prepare early childhood so that more potential is explored, mental readiness and maturity in attending basic education so that later they are ready to 
Effect of Marketing Strategy and Service Quality Against the Decisions of Parents

Amelia, Salamah, Sofyan

receive the material maturely and are more advanced compared to children who do not attend education in Early Childhood Education (PAUD).

One strategy that can be used by schools in achieving their vision and mission is marketing strategy. Marketing strategy has an important role to determine the achieving goals of vision and mission in a school institution. The marketing strategy can be a new development for schools to achieve the goals set, using a certain pattern of plans and tactics so as to attract the decision of parents to send their children to school.

Marketing strategy has an important role in a company or business (in this case the author discusses PAUD marketing strategy). Marketing becomes an absolute thing that must be implemented by schools, aside from being intended to introduce, marketing in educational institutions serves to have a good perspective on the institution and attract parents' students. In order to be able to maintain its existence, schools are required to be able to market their schools, because no matter how good a school is if it is not promoted to the maximum, the school will have an impact on the lack of students and the it's unfamiliarity among the community.

In marketing strategies of school institutions, attention needs to be paid to the dimensions of the service marketing mix, which consists of 7Ps, namely products, prices, places, promotions, people, processes, physical evidence evidence) and customer service. Marketing mix is one of the factors that influence consumer purchasing decisions (Astuti, Silalahi, \& Wijaya, 2015). But it is not only marketing that needs attention, schools also need to pay attention to the dimensions of service quality for students. Schools of interest to parents of students certainly have good service quality, quality. The quality of service provided by the school institution refers to the quality standards that meet the needs of consumers (parents) consisting of, reliability, responsiveness, responsiveness, conviction (convidence), empathy and Intangibles (tangible). The quality of service in an PAUD institution not only affects the implementation of PAUD going forward, but also affects to the development and growth of students in the PAUD institution.

Many demands and considerations of the community are often not matched by the quality of the PAUD institution. Considering that the knowledge of the parents' decisions on the quality of PAUD is very important for improving the quality of the institution, so that the PAUD institution can evaluate the quality of services provided by the institution and the institution can improve the quality in the future. However, measuring quality in education continues to be an annoying and difficult problem, even though most educational evaluations have used concrete criteria (Hadikoemoro, 2002). Word of mouth service quality has only been proven to have an indirect effect on satisfaction, behavior and intention to send their children to school due to the presence of PAUD that is not yet known to the surrounding community (Prentice, Brady, \& McLaughlin, 2018).

In this study, schools need to understand the circumstances and needs of students, so they can provide good quality of service. Schools also need to consider the conditions of the external environment and internal environment. Therefore, the success of a school marketing strategy depends on environmental conditions and ways of meeting the needs of related parties both internally and externally.

Early Childhood Education (PAUD) in PAUD Al Hidayah Pertiwi is still relatively new and also currently has students with quite minimal numbers. Therefore PAUD Al Hidayah Pertiwi 
Effect of Marketing Strategy and Service Quality Against the Decisions of Parents

Amelia, Salamah, Sofyan

needs to do marketing to attract prospective parents in the decision to choose a school. Marketing carried out in PAUD Al Hidayah Pertiwi, the manager and / or educator, plays a role in marketing activities. Marketing activities are supported by a good strategy, so that marketing activities which carried out can attract prospective parents of students. PAUD Al Hidayah Pertiwi unfortunately has not done an optimal promotion. PAUD Al Hidayah Pertiwi also does not have its own place or building, but it is still inside the Al Hidayah mosque hall in Kelapa Gading Timur District. Seeing this situation makes researchers interested in marketing strategies and the quality of services carried out in PAUD Al Hidayah Pertiwi, Kelapa Gading Timur District, towards the decision of parents of students. Various dimensions of service quality perception have a positive impact on parents' satisfaction (Tuan, 2012).

The results of previous studies stated that variables such as product, cost, and location, were not proven to influence parents' decision to choose Kasatriyan Elementary School. The marketing mix of services consisting of products, locations, processes, people, physical evidence, and service quality consisting of direct evidence, reliability, response, security, and empathy simultaneously have a positive effect on student satisfaction, while the cost of education has a negative effect (Gultom), Ginting, \& Sembiring, 2014). Marketing strategy and service quality significantly influence student interest in school at MTs Al Asiyah Cibinong (Kristiani, 2016). There is a significant positive effect between school location, customer satisfaction and school culture on the decision to choose a school, the dominant factor in influencing the decision to choose a school is the school location factor (Khasanah, 2012).

Family size, parental education level, parental income, staff qualifications and school performance are the main factors influencing parents' choices in the selection of private schools. Teaching media and teacher interests can also influence parents' choices. About $95.5 \%$ of surveyed parents believe that private schools produce confident students. Likewise, $88.5 \%$ thought that these schools had a progressive mode of education, $86 \%$ of parents avoided public schools because of an inappropriate education environment and $89.5 \%$ because more students were available from classes (Rehman, Khan, Tariq, \& Tasleem, 2010). Factors that significantly influence parents in making decisions in choosing SDIA 32 Padang are the quality of teaching, religion, school image, and school fees. Other factors such as teacher quality, school location, school facilities, school environment, and school safety had no significant effect (Rosha, Wati, \& Dharma, 2017).

\section{METHOD}

Research methodology can examine the sequence in the steps to be studied so that the results studied provide an understanding of how to determine or arrange knowledge from ideas and materials that refer to research. The paradigm is a research perspective used by researchers that contains how the world views of researchers look at reality, how to study phenomena, ways used in research and ways used in interpreting findings. This research paradigm shows the relationship that there is the influence of marketing strategies and the quality of services provided by PAUD Al Hidayah Pertiwi to parents of students. The research location is in Kelapa Gading Timur, Kec. Kelapa Gading, Kota Jakarta Utara Province D.K.I. Jakarta

In this study, the population is all parents of students who use educational services in $\mathrm{Al}$ Hidayah Pertiwi PAUD as many as 85 parents. The number of samples in the study were 70 parents from a population of 85 parents. The sample size is determined using the Slovin formula. 
Effect of Marketing Strategy and Service Quality Against the Decisions of Parents

Amelia, Salamah, Sofyan

Table 1. Definition of Variable Operations

\begin{tabular}{|c|c|c|c|c|}
\hline No & Variable & Dimentions & Indicator & $\begin{array}{c}\text { Scale of } \\
\text { Measurement }\end{array}$ \\
\hline 1 & $\begin{array}{l}\text { Marketing strategy } \\
\left(\mathrm{X}_{1}\right) \\
\text { (Astuti et al., 2015) }\end{array}$ & $\begin{array}{ll}\text { 1. } & \text { Product } \\
\text { 2. } & \text { Price } \\
\text { 3. } & \text { Promotion } \\
\text { 4. } & \text { The place } \\
\text { 5. Person } \\
\text { 6. Process } \\
\text { 7. Physical evidence }\end{array}$ & $\begin{array}{l}\text { 1. Level of teaching } \\
\text { comprehension } \\
\text { 2. Strategy and tactical } \\
\text { policy } \\
\text { 3. Relationship with } \\
\text { consumers } \\
\text { 4. Strategic environment } \\
\text { 5. Educator Resources } \\
\text { 6. Change of attitude } \\
\text { 7. Working conditions }\end{array}$ & Likert \\
\hline 2 & $\begin{array}{l}\text { Quality of } \\
\text { Service }\left(X_{2}\right) \\
\text { (Simmons, Dowell, } \\
\text { \& Small, 2013) }\end{array}$ & $\begin{array}{l}\text { 1. Reliability } \\
\text { 2. Responsiveness } \\
\text { 3. Confidence } \\
\text { 4. Empathize } \\
\text { 5. Manifest }\end{array}$ & $\begin{array}{l}\text { 1. The work is likert } \\
\text { 2. Ease of information } \\
\text { 3. Policy and level of } \\
\text { knowledge } \\
\text { 4. The level of } \\
\text { understanding of the } \\
\text { message } \\
\text { 5. Affordable level of } \\
\text { facilities }\end{array}$ & Likert \\
\hline 3 & $\begin{array}{l}\text { Parents Decision } \\
(\mathrm{Y})\end{array}$ & $\begin{array}{l}\text { 1. Product selection } \\
\text { 2. Brand choice } \\
\text { 3. Choice of purchase } \\
\text { channels }\end{array}$ & $\begin{array}{l}\text { 1. Ease of information } \\
\text { 2. Management policies and } \\
\text { practices } \\
\text { 3. Information Technology }\end{array}$ & Likert \\
\hline
\end{tabular}

The purpose of this study is to obtain answers to the problems that have been formulated above, including: (1) analyzing and knowing the effect of marketing strategies and service quality on parents' decisions; (2) analyze and determine the effect of marketing strategies on parents' decisions; and (3) analyze and determine the effect of service quality on parents' decisions. The research model is:

$$
\widehat{Y}=\alpha+\beta_{1} X_{1}+\beta_{2} X_{2}+\varepsilon
$$

Based on the regression model, the research paradigm can be described as follows:

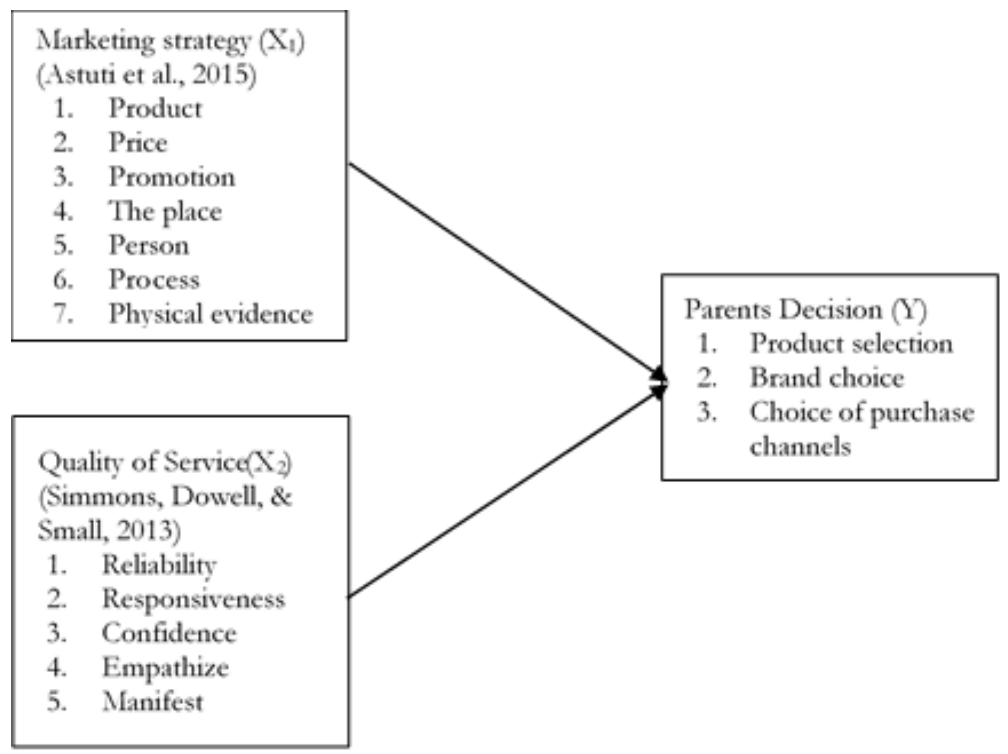

Figure 1. Research Paradigm 
Effect of Marketing Strategy and Service Quality Against the Decisions of Parents

Amelia, Salamah, Sofyan

Based on the research paradigm, the proposed hypothesis is:

$H_{01}: \beta_{1} \beta_{2}=0$ (there is no effect of marketing strategy and service quality on the decision of parents of students choosing PAUD Al Hidayah Pertiwi)

$\mathrm{H}_{\mathrm{a} 1}: \beta_{1} \beta_{2} \neq 0$ (there is an influence of marketing strategy and service quality on the decision of parents choosing $\mathrm{Al}$ Hidayah Pertiwi PAUD)

$\mathrm{H}_{\mathrm{o} 2}: \beta_{1}=0$ (there is no effect of marketing strategy on the decision of parents of students choosing PAUD Al Hidayah Pertiwi)

$\mathrm{H}_{\mathrm{a} 2}: \beta_{1} \neq 0$ (there is an influence of marketing strategy on the decision of parents of students choosing PAUD Al Hidayah Pertiwi)

$\mathrm{H}_{\mathrm{o} 3}: \beta_{2}=0$ (there is no influence of service quality on the decision of parents of students choosing PAUD Al Hidayah Pertiwi)

$\mathrm{H}_{23}: \beta_{2} \neq 0$ (there is an influence of service quality on the decision of parents of students choosing PAUD Al Hidayah Pertiwi)

\section{RESULT AND DISCUSSION}

Table 2. f-test result

ANOVAa

\begin{tabular}{llrrrrr}
\hline Model & & Sum of Squares & Df & Mean Square & F & Sig. \\
\hline \multirow{2}{*}{1} & Regression & 6,146 & 2 & 3,073 & 15,559 & $0,000^{\mathrm{b}}$ \\
& Residual & 13,233 & 67 & 0,198 & & \\
& Total & 19,379 & 69 & & & \\
\hline
\end{tabular}

a. Dependent Variable: The decision of the parents of students

b. Predictors: (Constant), Quality of service, marketing strategy

From the results of the $\mathrm{f}$ test it can be seen that there is a simultaneous influence of marketing strategy variables and service quality variables on the parents' decision variables as evidenced by the fcount $>\mathrm{f}$ table $(15.559>3.13)$.

Table 3. Summary of T-Test Results

\begin{tabular}{clccc}
\hline No & \multicolumn{1}{c}{ Variable Name } & T value & T table & Desicion \\
\hline $\mathbf{1}$ & Marketing Strategy & 0,802 & 1,996 & Not Influence \\
\hline $\mathbf{2}$ & Quality of service & 5,281 & 1,996 & Influenced \\
\hline
\end{tabular}

\section{Effect of Marketing Strategies on the Decisions of Parents of Students}

T-test results that the variable marketing strategy did not have a significant effect on the decision variables of parents showed the value of $t$ count $<t$ table of 0.802 . These results indicate that receiving $\mathrm{H}_{\mathrm{o} 2}$ which states that there is no effect of marketing strategies on the decision of parents of students choosing PAUD Al Hidayah Pertiwi. The results of this study are in line with the results of Christian research (2016). This shows that the location of SD Kasatriyan located within the ivory coconut housing complex mosque is not much known by the surrounding community. In addition, the growth of PAUD in Kelapa Gading makes parents of students have another alternative as an option to get their children to school. 
Effect of Marketing Strategy and Service Quality Against the Decisions of Parents

Amelia, Salamah, Sofyan

\section{Influence of Service Quality on Student Parents' Decisions}

Service quality variables affect the parents' decision variables as evidenced by the t value> $\mathrm{t}$ table of 5.281. These results indicate that receiving $\mathrm{H}_{\mathrm{a} 3}$ which states that there is an influence on the quality of service on the decision of parents choosing PAUD Al Hidayah Pertiwi PAUD. Which means that service quality has a positive effect on the decision of parents to send their children to PAUD Al Hidayah Pertiwi. This can be interpreted if the Quality of Service increases, so the decision of parents of students to increase their children's schooling in Al Hidayah Pertiwi. The results of this study are in line with the results of Christian research (2016), that the services which have been provided to parents of students when searching for information, registration up to the facilities offered for students who will enter PAUD Al Hidayah Pertiwi are able to be the main considerations of students' parents in choosing PAUD Al Hidayah Pertiwi as a place of learning for her children. This proves that the services provided by teachers and employees to parents are considered good or satisfying so that parents feel comfortable and entrust their children to attend PAUD Al Hidayah Pertiwi.

\section{CONCLUSION}

This study shows that there is no significant effect of marketing strategy variables on the parents' decision variables. From the observations of researchers that the lack of interest in marketing strategies such as not installing banners or banners in strategic places, distributing brochures, and introducing them through social media, places that are not yet strategic, cause a decrease in the attractiveness of parents to send their children to PAUD Al Hidayah Pertiwi.

Service quality variables affect the parents' decision variables. This is very closely related to services both before or after the services are felt by parents of students and good relationships and interactions. Therefore, good service will provide an encouragement to parents to establish a strong bond with PAUD Al Hidayah Pertiwi.

The suggestion in this study is that PAUD Al Hidayah Pertiwi school in providing services in the form of reliability of the school provides student acceptance services quickly and uses methods or characteristics in an interesting learning process, responsiveness of schools providing information quickly and precisely, the confidence (convidience) of teachers who teach have expertise in their fields, empathy (empathy) staff teachers and school principals give attention or listen to complaints from students' parents, and tangible) school buildings that pretty good, complete environment, toys. So that the quality of services provided by PAUD Al Hidayah Pertiwi to parents of students can be one of the factors parents choose to send their children to PAUD Al Hidayah Pertiwi. This research can be continued to the next researcher by looking for other variables that are broader in scope so that the research results are more perfect.

\section{REFERENCE}

Astuti, R., Silalahi, R. L. R., \& Wijaya, G. D. P. (2015). Marketing Strategy Based on Marketing Mix Influence on Purchasing Decisions of Malang Apples Consumers at Giant Olympic Garden Mall (MOG), Malang City, East Java Province, Indonesia. Agriculture and Agricultural Science Procedia, 67-71. https://doi.org/10.1016/j.aaspro.2015.01.015

Gultom, D. K., Ginting, P., \& Sembiring, B. K. (2014). Pengaruh Bauran Pemasaran Jasa dan Kualitas Pelayanan Terhadap Mahasiswa Program Studi Manajemen Fakultas Ekonomi Universitas Muhammadiyah Sumatera Utara. Manajemen Dan Bisnis, 14(1), 21-33. Retrieved from http://jurnal.umsu.ac.id/index.php/mbisnis/article/view/113/58 
Effect of Marketing Strategy and Service Quality Against the Decisions of Parents

Amelia, Salamah, Sofyan

Hadikoemoro, S. (2002). A comparison of public and private university students' expectations and perceptions of service quality in Jakarta, Indonesia. Retrieved from http://search.proquest.com/docview/305440753?accountid=13771

Khasanah, N. (2012). Faktor-Faktor Yang Mempengaruhi Orang Tua Dalam Pengambilan Keputusan Memilih Sekolah Dasar Swasta (SD Virgo Maria 2 dan SDIP. H. Soebandi Kecamatan Bawen Kabupaten Semarang). Satya Widya, 28(2), 137-146. https://doi.org/10.24246/j.sw.2012.v28.i2.p137-146

Kristiani, N. (2016). Faktor-Faktor yang Mempengaruhi Keputusan Orang Tua Siswa Memilih SD Kasatriyan Surakarta. Jurnal Manajemen Maranatha, 16(1), 91-118. Retrieved from https://journal.maranatha.edu/index.php/jmm/article/view/8

Prentice, G., Brady, J., \& McLaughlin, C. (2018). Education Service Quality, Value and Satisfaction on Student Customer Intentions and Behaviour. DBS Business Review, 2, 89-112. https://doi.org/10.22375/dbr.v2i0.27

Rehman, N. U., Khan, J., Tariq, M., \& Tasleem, S. (2010). Determinants of parents' choice in selection of private schools for their children in district Peshawar of Khyber Pakhtunkhwa Province. European Journal of Scientific Research, 44(2), 177-187. Retrieved from https://www.researchgate.net/publication/266874609_Determinants_of_Parents'Choice _in_Selection_of_Private_Schools_for_their_Children_in_District_Peshawar_of_Khyber_ Pakhunkhwa_Province/link/54de119f0cf2814662ecd739/download

Rosha, Z., Wati, L., \& Dharma., S. (2017). Faktor-Faktor yang Mempengaruhi Orang Tua dalam Pengambilan Keputusan Memilih Sekolah Dasar Islam Al-Azhar 32 Padang. E-Jurnal Apresiasi Ekonomi, 5(3), 139-147. Retrieved from http://stiepasaman.ac.id/ojsapresiasiekonomi/index.php/apresiasiekonomi/article/view/1 $31 / 182$

Simmons, P., Dowell, D., \& Small, F. (2013). The influence of fairness on university student satisfaction. International Journal of Assessment and Evaluation, 19(1), 1-16.

Tuan, N. M. (2012). Effects of service quality and price fairness on student satisfaction. International Journal of Business and Social Science, 3(19), 132-150. Retrieved from http://ijbssnet.com/journals/Vol_3_No_19_October_2012/15.pdf 